\title{
Exploration on Green Transformation of China's Textile Export Trade
}

\author{
Yayu JI \\ School of Economics and Management, Beijing Jiaotong University, China 100044 \\ sylvia_0o@126.com
}

Keywords: Green Transformation, Green Trade Barrier, Strategy.

\begin{abstract}
Textiles account for a large share of China's export trade and are a major component of China's export earnings. However, at present, the restriction of green trade barriers faced by China's textile export trade is increasing. This has a negative impact on the export of Chinese textiles to a certain extent, and seriously restricts the export trade of China's textiles. Green construction of China's textile industry is an effective measure to avoid green barriers in China's textile export trade. This paper focuses on the green transformation of China's textile industry, focusing on the current situation of China's textile products suffered from green barriers, the reasons why China's textile trade suffers from green barriers, and provides some suggestions and ideas for Chinese textile export enterprises to achieve green transformation, and explores corresponding measures from the government's perspective.
\end{abstract}

\section{Introduction}

China is the largest producer and exporter of textiles and clothing in the world. The textile industry is a traditional Chinese pillar industry, an important civilian production industry and an industry that creates new advantages in internationalization, but it is also an industry with high pollution, high emissions and high energy consumption. Under the background of serious environmental pollution, severe resource situation and the pursuit of sustainable development, the green transformation of China's textile enterprises is imminent. In 2012, the United Nations Conference on Sustainable Development, with the theme of "Developing a Green Economy", clarified the development approach of the global economy for green transformation. To realize the green transformation of enterprises is to coordinate and deal with the relationship between enterprises and nature, between enterprises and society, and within enterprises, so as to achieve the goal of "double health" of the earth and people.

With the ecological civilization and green development promoted to the height of national development strategy, the requirements of green transformation and upgrading of textile industry are gradually increasing. In October 2016, the "13th Five-Year Plan" of the textile industry released by the Ministry of Industry and Information Technology pointed out that for the textile industry, the goal of green development is to create a green production system for the industry, so that the clean production process can be used on a large scale. Under the 13th Five-Year Plan of the textile industry, China must achieve the basic goal of becoming a textile power in 2025. Transformation and upgrading are issues that need to be solved urgently.

Textile export trade is of great significance to the development of China's economy and is an important economic pillar industry in China. However, China's textile exports are facing more and more restrictions of green trade barriers, which to some extent have a negative impact on China's textile exports, seriously restricting China's textile export trade and becoming the main obstacle to China's textile exports. Under the goal of promoting sustainable development, in order to achieve the stable development of China's textile industry, the textile industry should accelerate the transformation and upgrading of the industry, and accelerate the pace of green transformation. 


\section{Literature Review}

With the increase of global population and the acceleration of urbanization, the consumption of resources and the loss of environment in the process of global economic and social development are increasing day by day, and the burden of the earth ecosystem is gradually increasing. People are more and more deeply aware of the bottleneck role of natural resources and environmental capacity system in the world economic and social development. In this context, in recent years, the research on green economy, green development and green transformation has become a research hotspot in the field of related disciplines. This paper briefly introduces the green transformation of textile industry at home, aiming to provide useful reference for further thinking and exploring the development strategy and decision-making of green transformation of textile industry in China.

\subsection{Proposal for Green Transformation of Textile Foreign Trade}

The domestic research on green transformation of textile foreign trade began in the 21 st century. Gui [1] (2000) concluded through research that the prohibition of some unsafe chemical dyestuffs in China's textile and clothing products exported to Germany and the Netherlands caused huge obstacles to the textile trade between China and Germany and Netherlands. Lu and Wang ${ }^{[2]}$ (2002), using the principle of political economy, showed the origin of the formation of the international green trade system, and analyzed the current situation of China's textile industry, suggesting that "ecological textiles" should be used to deal with green barriers. Liu ${ }^{[3]}$ (2015) elaborated the environmental pollution problems existing in China's textile industry, and proposed that the development and application of green textiles is the development trend of the international market.

\subsection{Research on the Path of Green Transformation of Textile Industry}

Guo and Zheng ${ }^{[4]}$ (2011) through the historical investigation and comparative analysis of the promotion path of green transformation at home and abroad, think that the market failure and the insufficient degree of social organization determine that the current green transformation with sustainable development strategy as the main line can only be a top-down drive of government behavior. Ling and Shen ${ }^{[5]}$ (2017) analyzed the operation mode and characteristics of green supply chain in textile industry, and put forward that the establishment of green information platform is the key to the establishment of green supply chain mode in textile industry, and green supply chain management is the need of textile enterprises to achieve long-term development.

\subsection{Literature Evaluation}

In conclusion, green economy and green development are inseparable from our life. Compared with the inefficient, conflicting and unsustainable economic structure in the past, green transformation is to change from the traditional economic structure to the efficient, harmonious and sustainable green economic structure. However, in the past, the research on green transformation of textile industry mainly focused on the strategy, policy, strategy, suggestion, etc. at the macro level, or the research on green transformation of textile industry at the prefecture, city and county level was the most, so it is worth exploring the green transformation path of China's textile export trade from a higher level combined with the macro connection of green transformation of textile industry among different regions.

\section{The Current Situation of China's Textile Export Trade Encountering Green Barriers}

With the gradual recognition of green and ecological concepts by consumers, the impact of the development trend of international green consumption on China's textile export trade is becoming more and more serious. Textile export and its larger share in the international market have been seriously hindered by the requirements of Textile Ecology. In addition, in view of the increasingly serious global environmental problems, various countries have begun to implement different levels of green barriers, which has brought serious impact on China's accession to World Trade and made China's textile foreign trade face more and more severe challenges. 


\subsection{The Situation of China's Textile Export Trade Encountering Green Barriers}

\subsubsection{Complex and Rigorous Green Technical Standards}

The EU has reformed the relevant green barrier laws every two months. So far, it has banned or restricted the use of 25 categories of more than 2000 varieties of textile dyes and textile auxiliaries. China's textile enterprises must obtain the relevant recognition of the EU in order to put their products into the European Union market or establish their own position in the global supply system. It is estimated that the cost of testing each chemical substance is about 85000 euros, which costs about 570000 euros to test a new type of substance, while the cost of testing nearly 2000 prohibited or restricted substances is really too high for China's small and medium-sized textile export enterprises.

In addition, as one of the world's developed economic communities, the EU plays a leading role on a global scale. Its strict chemical laws and supervision and management measures often echo other countries and regions. In addition to developed countries, developing countries have begun to imitate the development of their own chemical control systems.

At the beginning of 2016, the International Environmental Textile Association announced the latest version of the Oeko-Tex Standard 100 and the limit regulations, which raised the threshold for China's textile exports. In recent years, developed countries and regions represented by Japan, the European Union, and the United States have increasingly restricted the entry of Chinese textiles in terms of environmental protection regulations, safety and health standards, and green label recognition.

\subsubsection{The Damage is Getting Worse}

According to the estimate of the Ministry of Commerce, since 2000, the losses caused by green barriers to China's textile exports have exceeded 1 billion U.S. dollar each year, of which the accumulated losses caused by green barriers set up by the European Union, Japan and the United States account for over $75 \%$. After the financial crisis in 2008 , the trend became more and more obvious, and the losses caused by green barriers increased by more than $50 \%$. Recalling the recall cases of textile products announced by the European Union in 2015, 48\% of them are Chinese goods. According to the China International Trade Promotion Council Research Institute, the losses incurred by China's textile exports to the EU in 2015 due to various types of unqualified inspections accounted for $18.9 \%$ of China's total textile exports to the EU.

In the first quarter of 2018, the chemical risk notice issued by the European Union reported that there were 92 notifications of textile products exported from China due to chemical and environmental risks, accounting for $73.6 \%$.

\subsection{Analysis of The Causes of China's Textile Export Trade Encountering Green Barriers}

\subsubsection{Increased Trade Protection in Developed Countries}

China is the largest textile export country in the world, with a market share of more than one-third, which seriously restricts the development potential of other countries' textile products in China. Therefore, in order to protect the domestic market, countries continue to raise the threshold of green barriers against China's textiles, in order to achieve the goal of obstructing China's textile export trade.

Taking Japan as an example, at present, the Japanese consumer market pays more and more attention to the environmental protection and safety of textiles, and environmental protection textile certification and other issues are in order. Since the implementation of Law No. 112 on April 1, 2016, Japan has imposed strict restrictions on the formaldehyde content of all textile products and clothes exported to its domestic market and on the use of dual nitrogen compounds. For Shandong and even China's textiles, Japan is an important export market. More than $85 \%$ of Jinan's textiles are exported to Japan, and the value of exports is close to 100 million US dollars. Japan's restrictions on textile imports have a great influence on China's textile exports.

With the environmental and ecological issues being concerned by the international community, many countries have formulated and implemented a large number of green standards and certification systems. These certification processes and high costs are the "stumbling blocks" for China's textile exports. 


\subsubsection{Backward Science and Technology}

It is estimated that in the period of the 12th Five-Year Plan, China has caused more than 140 million tons of textile waste, which is consumed at a rate of more than $12 \%$ per year. However, the current recycling efficiency is less than $10 \%$. Although at present, China has begun to have some unique industrial reengineering processes for the recycling and application of textile products such as man-made fibers, and its international position in the product recycling market has been promoted, however, the technological frontier of the whole industry in China is still a long way from the developed countries such as Europe, America and Japan.

Developed countries such as the European Union, Japan and the United States have always focused on the individuality, popularity, environmental protection and high quality of products, and actively developed models and environmental protection products with high scientific and technological content. In contrast, the value of China's textile products is relatively low. Enterprises do not have enough business innovation, process innovation, brand innovation and modern marketing skills. They do not have unique research and development (R\&D) mechanism, patent technology and a certain degree of production scale, which means that the overall competitiveness of China's textile products is at a disadvantage in the international market.

\subsubsection{Imperfect Environmental Standards and Certification System in China}

Compared with developed countries, China's textile ecological standards are relatively low. The current "Technical Requirements for Eco-Textiles" (GB/T 18885-2009) has been in effect for nearly 9 years since the beginning of 2010, and has not been revised yet. However, the EU eco label will be updated every 3 to 5 years, and Oeko-Tex Standard 100 will even be revised once a year. Therefore, in the ecological standards of textiles in China, the limit indicators of toxic and harmful substances such as formaldehyde, heavy metal cadmium, organotin compounds and pentachlorophenol lag far behind the EU's eco-textile regulations, and the gap between China's standard and EU's eco standard will become an obstacle to China's textile export trade.

As far as the current situation is concerned, China's technical regulations and compulsory standards for ecological security are not perfect. Due to the limitations of their own conditions, most enterprises do not know much about international standards and technical regulations of trading countries, lack of awareness of environmental protection and certification strength, lack of warning and quick response system of green trade barriers, which has become an important reason for China's textile trade to suffer green barriers.

\section{Strategies for Green Transformation of China's Textile Export Trade}

In order to realize the green transformation of China's textile industry, the external needs of government policy guidance and support, and the internal needs to strengthen the construction of enterprise strength.

\subsection{Relevant Measures of the Enterprise}

\subsubsection{Achieve Green Design}

Green design refers to the consideration of product design and the impact on nature and resources from the whole stage of product entry to exit from the market. When the performance, quality, R\&D period and cost of the product are fully considered, various relevant elements are integrated to minimize the negative impact on the environment of the product and production period, so as to make the product reach the environmental protection standard. The research and development of green products must start with the green design of products. In order to realize the research and development of green products, enterprises should increase the investment in green design.

\subsubsection{Achieve Green Production}

Green manufacturing means that the products meet the requirements of green environmental protection in terms of technical safety, cleanliness and environmental protection standards, and produce ecological products with low environmental cost and high quality, including the selection of green raw materials and resources, and the adoption of more environmentally friendly substitutes and industrial facilities; enhance the improvement of production process and overall process; improve the 
overall application rate of resources and energy in the whole process of manufacturing materials; reduce the discharge of manufacturing waste; the products after use can be easily dismantled and recycled.

The focus of production greening is reflected in green procurement, clean production, elimination of lagging processes, technical equipment, and implementation of energy-saving and consumption-reduction technologies. Enterprises should actively develop and apply all kinds of green materials, accelerate the development of high-tech textiles, develop a variety of new green raw materials and green textiles, improve and improve the quality of materials used in China's textiles, and ensure the conformity rate of China's exports from the source.

\subsubsection{Implement Green Management}

China is a major producer of textile products and a huge consumer market. In order to maintain the status of the largest textile trading country in the world, Chinese enterprises need to carry out green operation. The development of green operation will greatly promote the economic growth of our country, and the international status and export competitiveness of our country will also be improved. More and more enterprises carry out green management, which will inevitably arouse people's interest in purchasing green textiles and enhance the concept of environmental protection of the whole people.

(1) Strengthen the construction of green culture in Enterprises

The green enterprise culture is the foundation of green operation, the guarantee of building ecological image and reaching green standard. The implementation of ISO14000 environmental management system can help from senior managers to ordinary employees to understand the environmental management system, improve the awareness of environmental protection of all employees, and determine everyone's responsibility in the system, thus creating excellent corporate culture and shaping outstanding corporate image.

The establishment of a green corporate culture has laid a solid foundation for the implementation of green business. Under the guidance of green corporate culture, enterprises will create a new "green effect" in the strategic, structural, research, manufacturing, sales, investment and other hubs, and effectively enhancing the competitiveness of enterprises.

(2) Establish green prices and create a green marketing system

In the R\&D process, green products increase the company's cost of environmental protection, and attach importance to human safety and health in raw materials, application requirements and "three wastes" treatment. Enterprises need to make use of the price system of green environment and regard environmental protection expenditure as an integral part of the price, and based on the consumer's "price perception" to draw up green prices. To a large extent, green price reflects the information in line with consumer psychology, which is likely to create consumer desire and improve the operation efficiency of enterprises.

In order to ensure the successful delivery of green textile products to consumers and avoid the existence of counterfeit and inferior goods, enterprises must implement green marketing strategy. Choosing the right partner requires them to have a green vision that is consistent with the company and the ability to collaborate to build a variety of green sales counters, use consistent green labels and offer a range of green products. In the operation and sales stage, enterprises should try to reduce channels to reduce pollution.

\subsection{Relevant Measures of the Government}

The growth of the textile industry is crucial to promoting the prosperity of the national economy, promoting the vigorous development of the market, creating employment opportunities, increasing national income, accelerating the progress of urbanization, and promoting the coordinated development of society. In the process of green transformation of China's textile trade, the government should play a leading role.

\subsubsection{Accelerate the Structural Adjustment of China's Textile Industry}

The government should encourage the development of low-pollution, pollution-free high-tech green industries, change the way of economic growth, and gradually shift from low-price competition to 
quality competition, and gradually shift from excessive use of resources to ecological development. In addition, the government should also give support to enterprises in developing ecological products, promoting ecological design, implementing green manufacturing and green consumption, and should encourage enterprises to accelerate the implementation of green transformation of production industry.

\subsubsection{Increase Support for Green Industry}

Green scientific and technological innovation can improve the product quality of enterprises and effectively eliminate some green trade barriers. However, some enterprises may not have enough financial resources to invest in green production projects, or have sufficient capacity to complete the development and implementation of green production projects. If we want our textile exports to occupy a place in world trade, the government must provide assistance to enterprises and help small and medium-sized enterprises to meet the strict international trade requirements.

\subsubsection{Improve Domestic Textile Ecological Standards and Related Legislation}

At present, China is in urgent need of establishing relevant laws and regulations such as ecological standards and technical requirements for textile production in line with international standards. With environmental protection, ecological balance and sustainable development as the core, China has formulated a number of green standards related to textiles. However, there is still a gap between China's standard and the international authoritative textile standard, which is not up to the high level of international standard, so it can't guarantee that China's textile products can successfully break the green barrier and realize the smooth export. Therefore, the relevant government departments need to establish a series of green textile standards in line with China's national conditions, establish and update relevant standards and regulations of China's textile manufacturing, and require textiles from the perspective of laws and regulations, so as to ensure the smooth export of China's products and maintain the status of China's textile export.

At present, there is a big gap between China's ecological standards and international standards. The government must pay close attention to the dynamics of ecological standards and relevant laws and regulations of all countries in the world, adjust the national standards in time, and formulate internationally recognized ecological standards.

\section{Conclusion}

China's textile industry has always maintained a steady and healthy development pace, its position as a pillar industry has not been shaken. Based on the above analysis, green barriers and China's economic transformation under the new normal are the reasons to promote the green transformation of China's textile export trade. Although the emergence of green trade barriers has brought heavy pressure to China's textile export, these pressures have also promoted the process of green transformation of China's textile export trade. In order to realize the green transformation of China's textile export trade, enterprises and the government must work together to take corresponding measures, actively develop new green textiles, pay attention to technological innovation, achieve the sustainable development of economy and ecological environment, step over the obstacles set by green barriers, go to the international stage with a new look, and promote the realization of green transformation of China's textile industry.

\section{References}

[1] Gui Jiaxiang, Green Textiles and Industry Countermeasures, China Textile Economy, vol. 1, pp. 46-52, 2000. (in Chinese)

[2] Lu Hong and Wang Yuqi, China's Garment Export and Green Trade Barrier, Science and Technology and Management, vol. 4, pp. 12-14, 2002. (in Chinese)

[3] Liu Wensheng, China's textile industry needs green production, Shanghai Maoma Technology, vol. 3, pp. 45-48, 2015. (in Chinese) 
[4] Guo Geying and Zheng Yufan, Analysis of the causes of the formation of the dynamic structure of green transformation in China, Science and technology innovation and productivity, vol. 1, pp. 53-54, 2011. (in Chinese)

[5] Ling Zichao and Shen Lanping, Establishment and Research of Green Supply Chain Management Mode in Textile Industry, Journal of Chengdu Textile College, vol. 34, pp. 155-158, 2017. (in Chinese)

[6] Xiang Tangxiang, Analysis of the Impact of Green Barriers on China's Textile Industry and Countermeasures, China High-tech Zone, vol. 2, pp. 1-2, 2018. (in Chinese) 